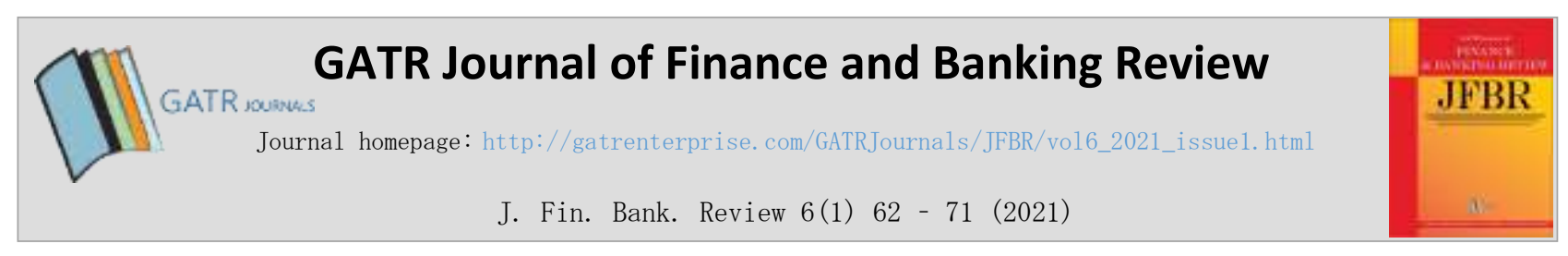

\title{
Taxpayer's Compliance: Towards Voluntary Compliance
}

\author{
Dian Purnama Sari ${ }^{1}$, Novrida Qudsi Lutfillah ${ }^{2}$, Sri Rahayu ${ }^{3}$, Yudi $^{4}$, Rahayu $^{5}$ \\ ${ }^{1}$ Widya Mandala Surabaya Catholic University, Dinoyo Street no. 42-44, 60265, Surabaya, Indonesia \\ ${ }^{2}$ Malang State Polytechnic, Soekarno Hatta Street no. 9, 65144, Malang, Indonesia \\ ${ }^{3,4,5}$ University of Jambi, Raya Jambi - Muara Bulian Street KM 15, 36122, Jambi, Indonesia
}

\begin{abstract}
Objective - This study aims to criticize the meaning of taxpayer's compliance.

Methodology - The paradigm used in this study is a qualitative design through dramaturgy theory.

Findings and Novelty - The result of the study indicates that the present taxpaying compliance is still equivocal with multi-interpretation. The term "less compliant" implicating compliance by a condition, neither completely compliant nor completely incompliant. The voluntary compliance targeted in taxpaying is purely determined by the morality of each taxpayer. The novelty of this research is the topic very interesting since there have been many topics talking about tax planning, self-corruption by taxpayers (an effort to reduce the reported amount of income tax), or some efforts to analyze influencing factors on the taxpayer's compliance, but does not study the definitions form taxpayer perspective.
\end{abstract}

Type of Paper: Empirical

JEL Classification: H1, H20.

Keywords: Tax; Taxpayer; Compliance; Voluntary Compliance; Awareness; Morality.

Reference to this paper should be made as follows: Sari, D.P; Lutfillah, N.Q; Rahayu, S; Yudi; Rahayu. (2021). Taxpayer's Compliance: Towards Voluntary Compliance, J. Fin. Bank. Review, 6(1), 62 - 71. https://doi.org/10.35609/jfbr.2021.6.1(3)

\section{Introduction}

Taxpayer's compliance has still been an interesting topic opened for more discussions. Why? The taxpayer's compliance has been always voluntary for nations under the self-assessment system. The system regulates taxpayers to count, submit, and make own report independently. This taxpaying independence very often indicates disobedience of the taxpayers in case of completely follow the regulation to be obediently paying the tax. It can be due to sorts of ignorance, on-purpose act, or compliant-like act. The understanding of taxpayer's compliance still remains a big question. In the case of the understanding of the taxpayer's compliance, when a taxpayer has fulfilled his obligation for on-time payment, but still has not correctly paid it yet, can it be categorized as a good and compliant taxpayer?

\footnotetext{
* Paper Info: Revised: April 16, 2021

Accepted: June 30, 2021

* Corresponding author: Dian Purnama Sari

E-mail: dian-ps@ukwms.ac.id

Affiliation: Faculty of Business, Widya Mandala Surabaya Catholic University, Indonesia
} 
Susanti, Dewi, and Sufiyati (2017), for instance, studied the taxpayer's compliance which differs from what is meant as compliance by Listyowati, Samrotun, and Suhendro (2018) who concentrated on the matter of taxpaying. Those, of course, are two different ways of understanding the taxpayer's compliance. In what state compliance is meant here? Is it when its fulfillment of, one of them or both of them, is completed? In another case, if taxpayers (it has been implemented in Indonesia since 2016 through 2017) follow tax amnesty, in which they do confession of missing tax reports they have been hiding during the time, could it be called compliance? For further question, will they become more compliant after their tax amnesty's confession? Imasius, Darijanto, Gani, and Soepriyanto (2020) found that trust towards the government has a positive leading role in the taxpaying regulatory compliance of the post-tax amnesty. Moreover, Sudarma and Darmayasa (2017) reported that the taxpayer's compliance does not instantly improve their taxpaying regulatory compliance after tax amnesty.

There have been some studies discussing the taxpayer's compliance. Its variety of variables covers: 1) tax cognition, 2) tax understanding, 3) sunset policy, 4) tax amnesty, 5) tax sanction, 6) taxpayer awareness, 7) tax authorities service, 8) taxpayer's willingness, 9) perception on service effectiveness, 10) tax automation, 11) taxpayer's environment, 12) tax tariff, and 13) many more. Those variables are based on Listyowati, Samrotun, and Suhendro (2018); Susanti, Dewi, and Sufiyati (2017); Mahfud, Arfan, and Abdullah (2017); Wiyarni, Hartini, and Djuharni (2018); Jotopurnomo and Mangoting (2013); Cahyani and Noviari (2019); Yusro and Kiswanto (2014); Vionita and Kristanto (2018). With a deeper dive, Handayani and Damayanti (2018) conducted a meta-analysis in their study through dependent variable (taxpayers' compliance) and found that all independent variables which include tax service quality, tax cognition, taxpayer's awareness, tax socialization, tax sanction, and taxpayer's attitude, positively influence on individual taxpayer's compliance in Indonesia. A number of studies on the taxpayer's compliance mentioned indicate that this topic is still a special concern, and the main focus tends to center on the factors affecting the taxpayer's compliance.

In fact, even though there are a lot of studies on the taxpayer's compliance, it still remains some problems related to its different definitions and parameters. Some define and view them from taxpayer's payment compliance, and some others see them in the matters of report compliance and administration. The biggest problem in this study is whether or not any taxpayer very compliantly reports his/her tax. It also may indicate that the taxpayers only show a performance of being compliant, while they still feel irritated during the time. What kind of compliance does fully describe the real one as "taxpayers" compliance? Is the term "compliant" best fit for an on-time taxpayer report? Is it for a taxpayer who reports and pays his/her tax based on the nominal amount? Perhaps, the term "compliant" is for both conditions? The other questions may also follow them. Is a taxpayer who pays and reports it on-time, but not the specific amount as should be, called "compliant"? On the contrary, can a taxpayer who submits or reports his/her tax correctly, but not on-time (late report), be labeled as "incompliant"?

All of the questions make us aware of what a taxpayer's compliance really is. This study does not refocus on influencing factors on the taxpayer's compliance. This study aims to criticize the understanding of the prospective taxpayers and the taxpayers about the taxpayer's compliance. It is sometimes measured from administrative regulation, punctuality, or willingness for payment. Unfortunately, self-understanding about the taxpayer's compliance has not been seriously taken for implementation. This topic is very interesting since there have been many topics talking about tax planning, self-corruption by taxpayers (an effort to reduce the reported amount of income tax), or some efforts to analyze influencing factors on the taxpayer's compliance, but does not study the definitions of it. This article is divided into introduction, literature review, research methodology, results, discussion and conclusion. 


\section{Literature Review}

\subsection{Taxpayers' Regulatory Compliance: How Can A Taxpayer Be Claimed as "Compliant"?}

The Decree of Minister of Finance of the Republic of Indonesia Number 544/KMK.04/2000 states that tax compliance is defined as an act of a taxpayer in the fulfilment of his/her tax obligation in accordance with the regulatory provisions and tax implementation regulation applicable in a country. The taxpayer who can potentially be called as a compliant taxpayer and has a right for a preliminary refund of tax overpayment is the one with the fulfillment of all criteria (Regulation of Minister of Finance, Number 192/PMK.03/2007 Verse 1) as follows: (a) on-time in the report of notification letter; (b) no tax arrears of all kinds, except that of with allowance for tax installment or tax payment delay; (c) financial report audited by a public accountant or government financial supervisory agency with unqualified opinion during 3 (three) months in a row; and (d) has never been convicted of committing any tax criminal act based on the court's sentence with a force of law remains during late 5 years. The taxpayers' regulatory compliance can be described as a feeling of guilt and shame, taxpayers' perception about reasonableness and fairness of tax burden they bear, the effect of satisfaction on government service (Maulida, 2018). Mardiasmo (2018) defines taxpayers' regulatory compliance as an awareness compliance nuance of tax obligation fulfillment, reflected in circumstances in which: (1) taxpayers understand or make efforts to comprehensively understand all of the tax regulations, (2) taxpayers fill out the tax form completely and clearly, (3) taxpayers correctly count their payable tax amount, and (4) taxpayers pay their payable tax on-time.

Oladipupo and Obazee (2016) mention two kinds of compliance theories: deterrence-based theory and psychology-based theory. The deterrence-based theory emphasizes incentive in which a taxpayer plays a role as a maximizer of amoral utility affected by economic motives such as maximizing benefits and detection probability. The assumption of tax compliance is due to psychological factors which include morality and ethics considered very significant for a taxpayer. In accordance with that, a taxpayer may obey the procedures and take risks, even for low auditing. Devano and Rahayu (2006) categorize taxpayers' regulatory compliance into two elements. Firstly, formal compliance, a condition in which a taxpayer formally fulfills his/her tax obligation based on procedures in tax regulation. Secondly, material compliance, a situation in which a taxpayer substantively fulfills all materials in taxation based on the regulation's content and meaning. This material compliance with tax regulation also includes what is called formal compliance.

Based on the concepts previously analyzed, it can be inferred that taxpayers' regulatory compliance should cover all regulations preceding implied and expressed. All must be unseparated, not fulfilling one-sided, and not ignoring one of them. But the next problems follow it. Is there still any compliance so-called as the real "being compliant"? Another one, is the presently existing taxpayers' regulatory compliance a mere pseudo?

\subsection{Dramaturgy as Research Method}

The term "dramaturgy" was firstly introduced by a monographer, Goffman, in 1956 entitled "The presentation of Self in Everyday Life". In his perspective, the reality is built in accordance with individuals interacting and influencing one another through characters they establish and impress. There are three keywords in dramaturgy theory, namely "control the conduct of others", "influencing the definition", and "impression". Kamayanti (2016) explains that the fundamental assumption about the human being brought by a researcher of dramaturgy should begin with: (a) human being essentially has a willingness to create and control his self-definition or certain situation towards the others; (b) His self-definition is used to control the others' behaviors based on his wants, and (c) the best way to make it real is through impression management.

Analysis technique follows Goffman's dramaturgy, which consists of: (1) performance; (2) team; (3) region and region's behavior; (4) discrepant roles; (5) communication out of characters; and impression management (Kamayanti, 2016). A dramaturgy-based study is able to analyze data by combining some or all of Goffman's analysis techniques. This study tends to focus on the performance in the data analysis. 
Performance has several components, namely: front, dramatic realization, idealization, maintenance of expressive control, misrepresentation, and mystification. Analysis of the performance in dramaturgy is presented in Picture 1.

\section{Research Methodology}

The paradigm in this study implements non-positivism aiming to criticize the taxpayers' regulatory compliance. The personal approach becomes a key point leading to an individual understanding about compliance which is not merely measured by using any sorts of quantitative measurement. This study goes through open dialogue with informants, and be analyzed by applying dramaturgy.

The term "dramaturgy" was firstly introduced by a monographer, Goffman, in 1956 entitled "The presentation of Self in Everyday Life". In his perspective, the reality is built in accordance with individuals interacting and influencing one another through characters they establish and impress. There are three keywords in dramaturgy theory, namely "control the conduct of others", "influencing the definition", and "impression". Kamayanti (2016) explains that the fundamental assumption about the human being brought by a researcher of dramaturgy should begin with: (a) human being essentially has a willingness to create and control his self-definition or certain situation towards the others; (b) His self-definition is used to control the others' behaviors based on his wants, and (c) the best way to make it real is through impression management.

Analysis technique follows Goffman's dramaturgy, which consists of: (1) performance; (2) team; (3) region and region's behavior; (4) discrepant roles; (5) communication out of characters; and impression management (Kamayanti, 2016). A dramaturgy-based study is able to analyze data by combining some or all of Goffman's analysis techniques. This study tends to focus on the performance in the data analysis. Performance has several components, namely: front, dramatic realization, idealization, maintenance of expressive control, misrepresentation, and mystification. As "Spectators" is used to label informants, functions as a specific term for data analysis emphasis in this dramaturgical study. The informants of the first scene consist of 20 people who are from personal taxpayers and prospective taxpayers, and the others of the second scene consist of 2 people working in the taxation division of companies. The dialogue process occurs openly.

\section{Results}

The data of this study is obtained through a scene created by the researcher in a class that uses taxation topics. The informants numbered 20 people who have different backgrounds. Some of them are workers and have become taxpayers. Some others are still considered prospective taxpayers. There are informants working in the taxation field, in accounting, and some of them have not worked yet. The study result is presented as follows:

\subsection{The First Scene: Taxpayers' Regulatory Compliance, Still Any?}

The first scene was taken by the researcher through a convincing performance of personal front at the beginning of the questions. The questions had been prepared and a room had been set up in specific nuance so that spectators were able to see the questions and watched the researcher standing in the middle of them. The first scene was begun when the researcher opened a question in the class by addressing the taxation topic. The researcher had prepared some questions through PowerPoint file presentation, so the questionand-answer session was saved and was able to read together. The classroom was rather quiet in the beginning until the researcher disassembled them by dramatically questioning "Have you heard about tax planning?", and they concurrently responded," Yes, we have." The researcher continued to question them "Have you ever heard about tax avoidance?" and they answered it synchronously, "Yes, we have". The 
researcher then responded their answer by giving another question "Okay, who dares explain what is called tax planning?" Some of the spectators started performing specific manners with smiles when hearing the question. One of the spectators, Lea, replied "a choice for tax burden minimization". Another spectator, Josh added it "If no way out, tax avoidance is the last choice". The researcher kept going by expressing "Like that? Really?". Hearing that with doubt as a part of the strategy of actor's expression management related to Lia and Josh's, some of the other spectators began to share more detailed answers. The answers got more developed, for example, "Manipulatively setting addition or reduction towards income and expenses for a lower tax burden by still procedurally following the applicable regulation", or "An effort to legally make payment for tax burden with lower cost", and some other sound-like responses. Since then, the class had already become more alive. Some of them with little whispers discussed it together with their next friends.

When the researcher asked them "then what makes it different from the answers responding to tax planning and tax avoidance?", all of the spectators remained silent. One of them, Vinda answered it "the tax planning is perhaps about a selection method in order to minimize the tax payment in accordance with the applicable law. The researcher replied "Hhhmm, how about the others, what do you think about Vinda's point of view?". Some of the spectators seemed to be nodding head and said, "maybe yes". "It means that the manipulating answers and those efforts can be taken out from tax planning, doesn't it?" the researcher continued asking them. They responded "yes" to it by collectively agreeing. The researcher still kept going by asking "If concluded, what the tax planning is?". One spectator, Riri, stated a conclusion. She said, "the selection method is based on the taxation regulation for tax burden minimization". The researcher confirmed "Do you agree with that? Okay, we together accept it, and now let's continue our discussion for the next topic, namely tax avoidance".

The researcher engaged them by saying "Come on, we have already talked about tax planning and agreed to what we discussed. Several confirmed have also been noted. Who else willing to explain about tax avoidance?". One of the spectators, Evi, tried to respond to it "the previous one, manipulating and adding or reducing the income or the expenses in order to minimize the tax burden based on the applicable regulations". The researcher implied "OK, the first answer, right?". "Hmmm. It is probably a way to not pay tax, isn't it?" said Josh. Some of the informants laughed in distinguished ways of social interaction during the scene. "Is that so...?", some tried to comment. "Yes, that is, for all, it's no need for tax reporting and expenses, both individual taxpayers and corporate taxpayers so that the condition would lead to a big loss for our country", he continued. The other informants kept laughing. "Nonsense does not really sound that easy", added by others. The more crowded the informants, the more personal comments. The researcher waited for a little while and observed the expressions shown by all spectators until they ended up with calmness. Not long after, Ella eventually answered "It is indeed an effort to pay tax burden with lower amounts through legal ways". Vinda added, "the effort is by finding the tax gaps". The researcher commented, "Hhmmm, okay.... Anymore? Or you all agree with Ella and Vinda?". Another informant noddingly affirmed, "It seems like that". Hearing their various answers, the performance seemed to be in an ideal phase since a viewpoint assumed the actor as somebody with authority in the class (idealization).

The researcher continued it by showing picture about the difference between tax planning and tax avoidance. They observed it. After a little while, the researcher reconfirmed "Based on the previous talk about tax planning and tax avoidance, we may call it as legal or illegal?" Those twelve spectators agreed to label it legal, but five of them seemed to be doubtful by stating legal and illegal. Vinda, for the last comment, said that "Yes, it is legal. But those activities have two sides, namely moral and immoral". It seemed to be getting more interesting since there had been another area of discussion, namely the morality aspect. Yet, the topic had not been taken to a serious talk. Still, most of them took a safe step through the "social front".

"If the majority believe that the tax planning and tax avoidance is legal, then I am in a context of compliance. Usually, "compliant" is related to regulation obedience, isn't it?", the researcher explained. Some of the informants seemed to be nodding. The researcher tried to clarify, "It means that being compliant 
can be said to be legal when following the regulations, doesn't it? The researcher did another approach by stating "When the taxpayers arrange their tax planning, could it be called as "compliant"? The other side is when the taxpayers do tax avoidance, could it also be claimed as a "complaint?"

Again, some got started being silent. A while later, there was a response, "The tax planning could be named as compliant, Ms., since it tried to adjust with the regulations. On the contrary, the tax avoidance could be labeled as compliant, less compliant, dan incompliant". "Hahahahaha....", the researcher, and some informants laughed. The researcher clarified "My question was about two sides, namely compliant and incompliant". "Then why was there a black and white area? Less compliant?", the researcher asked.

Less compliant, hmmm, has become a black and white side of compliance. This phase of performance has already reached misrepresentation in which prospective spectators have started being doubtful of their initial understanding about taxpayers' regulatory compliance. In the researcher's impression, it seemed like passing through a yellow sign of traffic light which turns to a red sign when no traffic warden keeps watching them. It indicated that most of them tend to support the term "LESS COMPLIANT". It is true. The black and white side is undeniable. However, on that black and white side, does it mean that self-forgiveness becomes simpler when committing what is in fact "incompliant" to be something addressed as "compliant"?

Since there was a black and white side, namely less compliant, the researcher asked the informants. "What does the taxpayers' regulatory compliance mean to you?" Some informants originated some interesting answers. "Submit and report it as required in the applicable regulation,"Riri answered. On the other side, Kurnia responded by saying "Fulfilling the taxation obligation (Taxpayer Identification Number, paying tax as regulated)". Another answered it by giving an opinion "Self-assessment System has been operated". The other opinion as the answer was "Reporting the business activities in real condition, and obeying the applicable tax regulation". Another interesting answer by Anne was "Ontime tax reporting and paying". Josh added, "Accepting all tax regulation without any intention to avoid the regulation". Vinda ended up with an opinion, "It is administratively compliant but morally degraded". All of the answers or responses indicate that theoretically, many people are aware of being compliant taxpayers. The next problem, is the taxpayers' regulatory compliance really existing?

For a deeper discussion on the taxpayers' regulatory compliance, the researcher firmly asserted that compliance is not merely a single category. It is categorized into two groups, namely formal compliance, and material compliance, as explained by Devano and Rahayu (2006). It is then another question following if only fulfilling one of two, is it still tax compliance? In fact, only $30 \%$ of the informants confirmed with the answer "if not fulfilling one of them, it is then called as incompliant". While some other $60 \%$ of the informants considered it as "compliant". Through that point, there was one interesting statement amongst the informants, in coincidence working in the taxation. The one answered, "It is our daily routine at work, such as planning tax, and the like". "Yes, being compliant is ...." the informant sounded gradually doubtful. Some informants started whispering which indicates to which point the dialogue would end. Some had also felt inconvenient since the emerging talks. Finally, the scene with light dialogues was then ended with an impression expressed by the spectators who got started questioning to what extent the meaning of compliance in their minds. This scene was continued by showing some findings with different perspectives of variables discussing the taxpayers' regulatory compliance which had been talked about enough and not taken as data of this study.

\subsection{Taxpayers' Regulatory Compliance: Still Any?}

Taxpayers' regulatory compliance has become a very interesting topic. By regulation and theory, it has already had a very clear definition and understanding of compliance. Though so, it is still a questionable and debatable term to understand as a real taxpayer's regulatory compliance. The problem today, compliance has become "a horrifying thing" for the taxpayers and the prospective taxpayers. When admitted "incompliant", a taxpayer feels guilty. On the contrary, claiming "compliant" leads to a different feeling (incompliant enough). Hence, the term "Less Compliant" is used to reflect that condition. Being less compliant becomes 
a justification for incompliant compliance or compliant non-compliance. It then has emerged the use of misrepresentation in a performance indicating the spectators' perspective rather than the actors. The actor only offers "compliant" or "incompliant". On the other side, the spectators show the ambiguity of strategy in which they realize that saying "incompliant" would end with sins while saying "compliant" would also take them to a situation in which their nature tends to admit it as something "incompletely compliant".

"Tax planning could be said to be compliant since it adjusts with the regulation, Mam. Meanwhile, tax avoidance could be labeled as compliant, less compliant, and incompliant". The statement made all informants and the researcher laughed. It seemed like making fun of ourselves. It was a dramatic side. We have already known that we are not suitably labeled as compliant. By contrast, to be called incompliant is also something protested. Human always makes self-justification and is trying his best to make it good/proper though it is sometimes "bad/improper". Taxpayers' regulatory compliance has been becoming more complicated (unachieved compliance, calling them "incompliant" is something refused). In the end, the term "less compliant" is best to fit a trouble-free situation. It is indeed incompliant compliance but still remains refusal for being called as "incompliant".

A habit usually becomes a character uneasy to change. It is already a habitual habit and accustomed to doing it (very often acted). For those who have been accustomed to managing tax planning and tax avoidance, that kind of activity has been usually and commonly taken. As long as the tax planning and tax avoidance are legal, the taxpayers can be considered "compliant". Sooner or later, tax planning and tax avoidance will have become more common or "natural" to do. It is supportively shaped by the environment where it occurs around. Many other people sharing the same jobs also do the same. Boss also hoped me to help legally alleviating the tax burden of the company. As long as legal, it is then "compliant". It's true that during the time, the problem is not about aggressive tax planning or unacceptable tax avoidance. If so, it is still "compliant". But, is it right?

There was a joke saying "Hhhmmmm, it is probably a way for us to not paying tax, right?". It invited more laughs, "Why so?" That joke had actually implied compliance. When planning and avoiding the tax, its essential goal is to reduce the tax burden so that the tax can be much lower to pay. Does that kind of activity also indicate non-compliance, doesn't it?

One of the other informants, Nadya who works as a tax division officer in her company told her works in cases of calculation, payment, and reporting of Periodic Tax Return of Value Added Tax. The Value Added Tax (VAT) should be in a state of the underpayment which must be reported at 5\% - 7\% of the Sales VAT in which the tax consultant proposes the ranging percentage $(5 \%-7 \%)$. The VAT reporting technique has been being a yearly practice in past years (from year to year). Its implementation is in cooperation with the third party, one of the normal practices committed.

It is correlated with Nadya's experience in which she said "Invoices received are not due to goods purchase as listed in the tax invoices. Free from "(un)fairness" in the calculation of Value-Added Tax by a company, Nadya views that the company has overall been being formally and materially compliant by obeying all the applicable taxation regulations in counting and reporting the tax calculation completely, correctly, and on-time. But, behind the tax reporting which has fulfilled the legal-formal regulation, the VAT calculation has still substantially remained a distinguished interpretation, a black and white side essentially related to non-compliance.

The VAT reporting technique has been being a yearly practice in past years (from year to year). Its implementation is in cooperation with the third party, one of the normal practices committed. Free from "(un)fairness" in the calculation of Value-Added Tax by a company, Nadya views that the company has overall been being formally and materially compliant by obeying all the applicable taxation regulations in counting and reporting the tax calculation completely, correctly, and on-time. But, behind the tax reporting which has fulfilled the legal-formal regulation, the VAT calculation has still substantially remained a distinguished interpretation, a black and white side essentially related to non-compliance. The VAT reporting technique in the companies is a habitual practice acted from year to year. Cooperation with a third 
party is one of the normal practices. As mentioned, Nadya experienced it and indicated that "the invoices accepted are not due to the listed goods in the tax invoices. In this matter, the company purchases the tax invoices from the suppliers".

She closed her statement by expressing "Actually, it is awareness from heart saying it is not completely right for what has been done. But, what to do more? It has already become a tradition (very habitual and accustomed to doing the incompliant acts). Eventually, a condition of compliance has always been black and white as long as it is procedurally legal.

Based on the previous description, what is the most important thing in taxpayers' regulatory compliance is a condition in which the tax regulation is still a major point of consideration to obey. As long as it follows the regulation, it is just fine. If legal, no matter. However, a compliant person should have followed all the regulations, formally and materially. Have all the processes followed what are said in the Minister of Finance (MoF) Decree, Number 192/PMK.03/2007 Verse 1? Or, all processes have probably fulfilled the criteria mentioned by Mardiasmo (2018), in the matter of understanding and trying to understand all the tax regulations, to fill out the tax form completely and clearly, to calculate the tax payable correctly, and pay it on time. A condition of being compliant means that all the regulations are obeyed. It is not just a single or two regulations, but all. Even though there is a compliance side existing, is it then called COMPLIANCE?

Tuti have the same experience. By doing so, the incoming stock when being registered is different from that stored in the warehouse. The incoming stock is registered higher in number than that of stored. That kind of policy in the registration had caused the cumulation. If there is underpayment that has not gained $2 \%$, it will be "forced" to obtain that percentage level $(2 \%)$. Some informants stated that "As long as it is done by following the regulations, it is then categorized as "compliant", legal in another term.

\section{Discussion}

The taxpayers' regulatory compliance is an intentional manifestation of each taxpayer. The "light" dialogue indicated that the informants indeed realized that the taxpayers' regulatory compliance assumed to be "compliant" during the time may lead to the category of "incompliant". But, of course, they felt doubtful to call themselves "incompliant". Therefore, a black and white side emerges up as "less compliant". A selfjustification of non-compliance indicates that the taxpayers' regulatory compliance tends to be easy-arguing with no end. "LESS COMPLIANT" signifies that human being indeed has no willing for a feeling of guilt in a state of being incompliant. "LESS COMPLIANT" indicates that the human indeed cannot accept his guilt by a claim, namely "incompliant". In this case, "LESS COMPLIANT" still remains a value of compliance beside it also has lower non-compliance. The taxpayers' regulatory compliance is so highly complicated that the compliance itself is up in the air (undefined).

Based on the informants, the compliance seems to be still fragmented. The compliance has not become a holistic condition in which all criteria of the compliance must be fulfilled. If still remaining the criteria of compliance, it may be called "compliant". So, the criteria of being less compliant can be black and whitesided (compliant and incompliant). Why is the term "Less Compliant" emerging up? Occasionally, we do realize that "incompliant" is a hard thing. In fact, when we say "incompliant", it has implied disobedience of the regulation. On the other hand, saying "less compliant" has clearly signified non-compliance. At least, it still presents an internal feeling of "compliant". "Incompliant" indicates a sidestep non-compliance which sounds to be "compliant". It is said to be "sidestep" because of being unsuccessfully free so that it is still unable to get out from the situation (Widodo, 2013). "Less compliant" means non-compliance which refers to something unable to do abruptly (to the point).

The major phenomenon coming up behind taxpayer compliance is the system of self-assessment which enables the individual and corporate taxpayers to manipulate data based on the income. It is because the tax authorities cannot get involved in the income tax calculation process of the taxpayer. Nadya said that "the calculation of the VAT is very simple since it provides a program so that the data of Tax Basis (TB) and Value Added Tax (VAT) for every sale (Output Tax Invoice) and purchase (Input Tax Invoice) can directly 
be inputted". Nadya's statement affirmed that the company's taxpaying compliance in written format is complete (done). The documents and all of its requirement items are completely available as system or procedure.

In relation to that, a big question comes up. Is the taxpaying factually real? Nadya and Tuti gave answers simultaneously. "To this time, yeah ...all people have got that"- "It's no need to ask more about it, guys!" Through implicit smiles in their expression, there was a recognition to being compliant, but not (fully) fair. It was what Nadya and Tuti meant in their expression. This compliance phenomenon is very interesting to be supported with problem-solving. How is a person guided to be aware of voluntary compliance? The taxpayers' trust and awareness become the main pillars leading to a state of voluntary compliance. The essential part of voluntary compliance is building ethics and morality as a protective way for taxpayers to assess their own compliance.

Of all informants, it was only one of them who mentioned morality correlated to compliance matter. The informant managed to know that COMPLIANCE cannot be viewed from what people think on the surface. The taxpayers could be seen as very compliant. They in fact hide more incomes undetected by the taxation system. When the human takes control of morality, voluntary compliance can be achieved without any hindrances in all directions. Tax Directorate General must aware about morality and awareness. Tax Directorate Generela is expected to be able to raise awareness of early taxpaying, for instance through targeting prospective taxpayers by one of them, building relations to schools and higher education.

\section{Conclusion}

The result of the study indicates that the present taxpaying regulatory compliance is still equivocal with multi-interpretation. The term "less compliant" implicating compliance by a condition, neither completely compliant nor completely incompliant. Taxpayers still feel obedient, even if only "less compliant". The voluntary compliance targeted in taxpaying is purely determined by the morality of each taxpayer. The implication of this study is Tax Directorate General is expected to be able to raise awareness of early taxpaying, for instance through targeting prospective taxpayers by one of them, building relations to schools and higher education.

The limited number of respondents in this study has become a challenging factor due to the qualitative method applied which focuses on the information depth, so that the research results cannot be generalized. This study is still a conceptual area, so the studies following it have the opportunity to quantitatively analyze voluntary compliance for a reliable measure. Further research can also add to the understanding of taxpayer compliance from different sides, for example Tax Directorate General or Tax Consultants.

\section{References}

Cahyani, L. P. G., \& Noviari, N. (2019). The Effect of Tax Rates, Tax Understanding, and Tax Sanctions on SME Taxpayer Compliance. E-Jurnal Akuntansi, 26(3), 1885-1911.

Devano, S., \& Rahayu, S. K. (2006). Taxation: concepts, theories and issues. Jakarta: Kencana.

Handayani, O., \& Damayanti, T. W. (2018). Determinants of Individual Taxpayers' Compliance in Indonesia: A MetaAnalysis. The Indonesian Journal of Accounting Research, 21(1).

Inasius, F., Darijanto, G., Gani, E., \& Soepriyanto, G. (2020). Tax Compliance After the Implementation of Tax Amnesty in Indonesia. SAGE Open, 10(4), 2158244020968793.

Jotopurnomo, C., \& Mangoting, Y. (2013). The effect of taxpayer awareness, quality of tax service, tax sanctions, taxpayer environment on individual taxpayer compliance in Surabaya. Tax \& Accounting Review, 1(1), 49.

Kamayanti, A. (2016). Construction Methodology of Accounting Research Grounding Religiosity. Jakarta: Rumah Peneleh Foundation.

Keputusan Menteri Keuangan No.544/KMK.04/2000 concerning Criteria for Taxpayers Who Can Be Given Preliminary Refunds of Excess Tax Payments of the Minister of Finance of the Republic of Indonesia. 
Listyowati, Samrotun, Y. C. \& Suhendro. (2018). Factors Affecting Taxpayer Compliance in Paying Taxes. Airlangga Journal of Accounting and Business Research, 3(1), 372-395.

Mahfud, M. A., Mahfud, S. A., Arfan, M., Mahfud, S. A., Arfan, M., \& Abdullah, S. (2017). The Effect of Understanding Tax Regulations, Awareness of Paying Taxes and Quality of Tax Services on Corporate Taxpayer Compliance (Empirical Study on Cooperatives in Banda Aceh City). Journal of Accounting Administration: Unsyiah Postgraduate Program, 6(3).

Maulida, A. (2018). Compliance with Tax Payments for MSMEs (Micro, Small and Medium Enterprises) After the Issuance of Government Regulation Number 23 of 2018 in Kotagede, Yogyakarta. Journal of MSME Dewantara, 1(2), 18-27.

Oladipupo, A. O., \& Obazee, U. (2016). Tax knowledge, penalties and tax compliance in small and medium scale enterprises in Nigeria. IBusiness, 8(1), 1-9.

Finance, P. K. A. K. M. (2007). Regulation of The Minister of Finance Number 32/PMK. 03/2007.

Sudarma, I., \& Darmayasa, I. N. (2017). Does voluntary tax compliance increase after granting tax amnesty?. Accounting and Finance Review (AFR) Vol, 2(3).

Susanti, M., Dewi, S. P., \& Sufiyati, S. (2017). Taxpayer Reporting Compliance (Case Studies in West Jakarta and Tangerang). Journal of Business and Accounting, 19(2), 141-156.

Vionita, V., \& Kristanto, S. B. (2018). The Effect of Tax Socialization, Taxpayer's Awareness, and Tax Sanctions on Tax Compliance for Prospective Taxpayer. Journal of Contemporary Accounting, 10(2), 81-91.

Widodo, D. I. (2013). The Tale of Surabaya in the Past. Surabaya: Dukut Publishing.

Wiyarni, W., Hartini, H., \& Djuharni, D. (2018). The Effect of Tax Regulation Complexity, Quality of Service, Tax Sanctions And Audit On Tax Compliance. Journal of Contemporary Accounting, 10(1), 14-23.

Yusro, H. W. \& Kiswanto. (2014). The Influence of Tax Rates, Tax Payment Mechanisms and Awareness of Paying Taxes on MSME Taxpayer Compliance in Jepara Regency, Accounting Analysis Journal, 3(4), 429-436.

\section{Appendix}

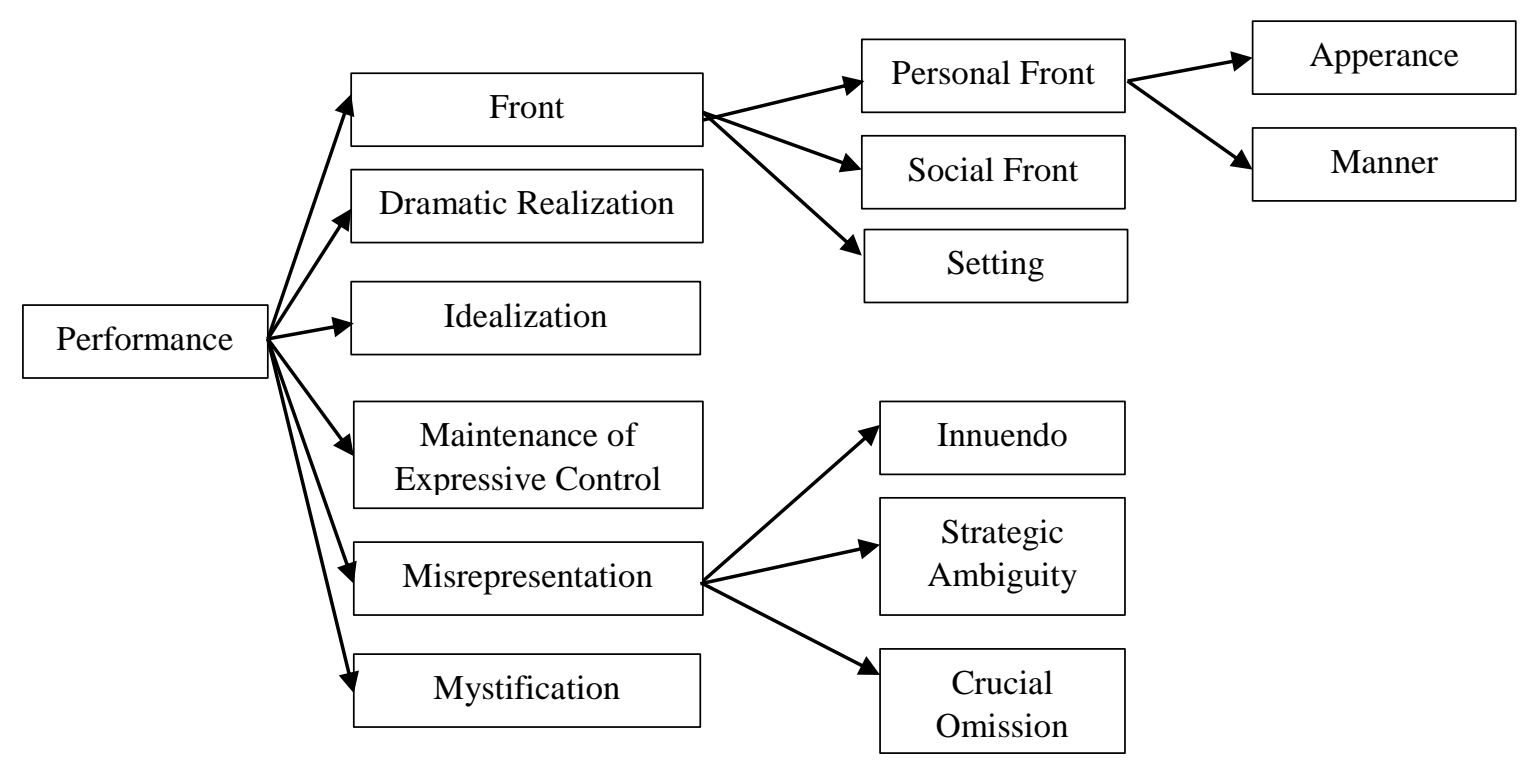

Picture 1. Analysis of The Performance in Dramaturgy Source: Kamayanti (2016) 